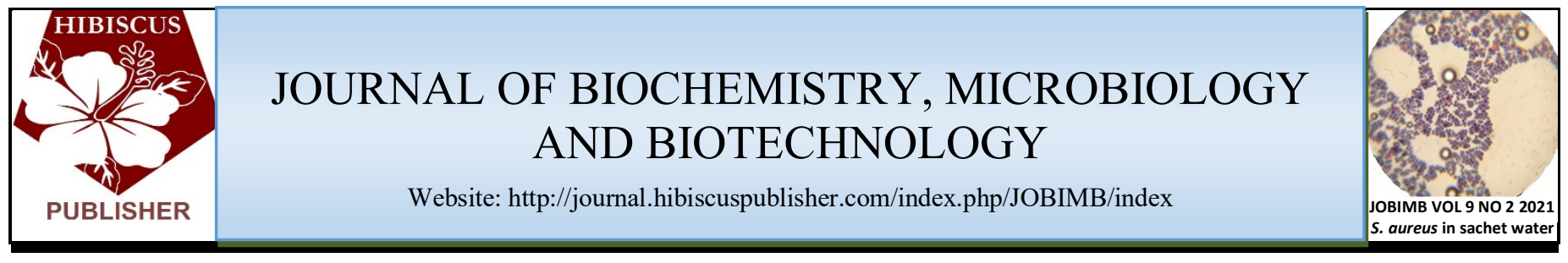

\title{
The Effect of the plant Adiantum philippense Extracts on Biofilms Formation and Adhesion to Shigella flexneri: A Predictive Modelling Approach
}

\author{
Garba Uba ${ }^{1 *}$, Abdulhadi Yakubu ${ }^{1}$ and Abdussamad M. Baba ${ }^{2}$ \\ ${ }^{1}$ Department of Science Laboratory Technology, College of Science and Technology, Jigawa State Polytechnic, Dutse, PMB 7040, \\ Nigeria. \\ ${ }^{2}$ Department of Biology, Aminu Kano College of Islamic Legal Studies, Kano, Nigeria. \\ *Corresponding author: \\ Garba Uba \\ Department of Science Laboratory Technology, \\ College of Science and Technology, \\ Jigawa State Polytechnic, Dutse, \\ PMB 7040, \\ Nigeria. \\ Email: garbauba@jiigpoly.edu.ng
}

\section{HISTORY}

Received: $28^{\text {th }}$ Oct 2021

Received in revised form: $23^{\text {rd }}$ Nov 2021 Accepted: $21^{\text {st }}$ Dec 2021

\section{KEYWORDS}

Shigella flexneri

Modified Gompertz

Adiantum philippense

Biofilm

modelling

\begin{abstract}
In the quest for novel bioactive metabolites, which can also be used as therapeutic agents, Adiantum philippense (A. philippense), an ethnomedically important fern, has become a fascinating herb. In this study, the predictive mathematical modelling of A. philippense crude extract was tested against Shigella flexneri, a common food pathogen for its phytochemical constituents, antagonistic ability, and effect on bacterial adhesion and biofilm formation was calculated. Various kinetics models such as Von Bertalanffy, Baranyi-Roberts, modified Schnute, Modified Richards, Modified Gompertz, Modified Logistics and latest Huang were used to get values for the above kinetic constants or parameters. modified Gompertz of the entire model was found to be the best model with the highest adjusted $R^{2}$ value and lowest RMSE value. The accuracy and bias factors values were close to unity (1.0). The maximum specific growth rate $\left(\mathrm{m}_{\max }\left(\mathrm{h}^{-1}\right)\right.$ for $S$. flexneri treatment with A. philippense extract was significantly much lower $(\mathrm{p}<0.05)$ with a value of $0.292(95 \%$ confidence interval of 0.254 to 0.331$)$ compared to control with a value of 0.540 (95\% confidence interval of 0.481 to 0.599$)$ indicating potential biofilm inhibition.
\end{abstract}

\section{INTRODUCTION}

Adiantum philippense is a small and delicate fern native to the Philippines. Rhizome is short and sub-erect, with scales covering the apex and being linear and a little wider at the base. Stipes are tufted, slender, dark brown, glossy, and glabrous, with lengths ranging from 5 to $21 \mathrm{~cm}$. Fronds are tufted, herbaceous, and arching in shape. Stipe up to $20 \mathrm{~cm}$ long, dark brown to black in colour, glossy, and glabrous in appearance. The lamina is 3611 $\mathrm{cm}$ long and linear to lance in shape, with the exception of a glabrous projection of the rhachis of varying length that often terminates in an inflorescence or proliferous bud or lamina with a terminal pinna. Rhachis, petiole, and pinnae are totally glabrous. Pinnings numerous (up to 15 pairs), persistent, lunulate, petiolate, alternating; $25-50 \times 13-25 \mathrm{~mm}$, decreased in size toward the apex, midrib forms the lower edge, outer border irregularly cut into wide lobes, apex decreased in size toward the midrib. The sori are oblong to linear in form and as long as the lobes are wide. [1-3].
The genus Shigella is designated after the Japanese physician Kiyoshi Shiga, who conducted study into the causes of dysentery. The year was 1892, and Shiga was a student at the Tokyo Imperial University School of Medicine, at which time he heard a lecture by Dr. Shibasburo Kitasato. Following graduation, Dr. Shiga was inspired by Dr. Kitasato's brilliance and boldness and decided to work for him as a research assistant at the Institute for Infectious Diseases. During the summer of 1897, Shiga concentrated his attention on what the Japanese called a "Sekiri" (dysentery) epidemic in the area. /These outbreaks, which were particularly harmful to the Japanese people in the late nineteenth century, happened on a regular basis. The sekiri pandemic of 1897 killed more than 91,000 people and resulted in a death rate of more than $20 \%$. [3] Shiga conducted a study on 32 dysentery victims and utilised Koch's Postulates to successfully isolate and identify the bacteria that was responsible for the ailment. The bacterium was studied and characterized further, with the identification of the bacterium's toxin producing techniques, i.e. 
Shiga Toxin, and he labored relentlessly to develop a vaccine against the sickness. Shigella flexneri is a Gram-negative bacterium that belongs to the Shigella genus that can cause diarrhea in humans when it infects them. Shigella flexneri is a member of the B serogroup of bacteria, which also comprises numerous other Shigella species. Certain strains of S. flexneri, on the other hand, have developed resistance to antibiotics that are frequently used. More serious problems can be treated more regularly because they become more resistive to treatment in the future. [1] Shigella can be distinguished from E.coli based on pathogenicity, physiology (inability to decarboxylate lysine or ferment lactose), and serology, among other factors.

Foodborne infections have the potential to cause long-term damage or death. Some examples of dangerous food include uncooked foods of animal origin, fruits and vegetables that have been infected with faeces, and raw shellfish that has been exposed to marine biotoxins[1]. The most main signs of these foodborne pathogens are diarrhoea, vomiting, stomach cramps, weakness, nausea, and fever. Vomiting and diarrhea are the most common side effects of these pathogenic organisms. These viruses have the potential to infect products at any moment throughout the production, distribution, and storage processes. It is consequently critical that we limit the establishment and development of food pathogens, despite the fact that removing these species is challenging due to their ability to firmly and adhesively adhere themselves to surfaces [5].

Microbes adhere evenly to surfaces and secrete extracellular polysaccharides, leading in the creation of biofilms on those surfaces. Increasing antimicrobial resistance among organisms associated with biofilms has resulted in biofilms becoming a substantial public health threat [4]. Additionally, biofilm bacterial cells are capable of protecting themselves against a number of physico-chemical aggressions, including acidity, salt, toxic metals, ultraviolet rays light, and phagocytosis (phagocytosis is the process by which bacteria ingest other bacteria) (Adnan et al., 2020a). Microorganisms bind to surfaces uniformly and produce extracellular polysaccharides, resulting in biofilm formation. Due to the increased resistance of biofilmassociated species to antimicrobial agents, biofilms present a significant public health problem [4].

In addition to being immune to antibiotics, biofilm bacterial cells are also able to protect themselves against a variety of physico-chemical aggressions, including acidity, salinity, heavy metals, ultraviolet light and phagocytosis[5]. According to the facts, the formation of biofilm poses a significant global threat to the marine and oceanic sectors, as well as to the food and dairy industries, and, most importantly, to public health worldwide (Adnan et al., 2020a). Biofilm treatment is a global concern that necessitates the development of innovative natural bioactive compounds that are effective against harmful bacteria found in food. In comparison to chemically generated bioactive compounds, the requirement for naturally occurring bioactive compounds is a result of interactions with the food industry.

It has been discovered in prior investigations on traditional medicines that phytochemicals have antibacterial properties through the suppression of quorum sensing [6-8]. A variety of phytochemicals, including flavonols, flavonoid, phenolic compounds, and flavonones, are recognised and widely used as quorum-sensing inhibiters. Flavonols are the most well-known and widely used. Likewise, these types of phytochemicals are also well-known for their ability to block bacterial adhesion as well as gene suppression, both of which are linked with biofilm development [9-14]. Therefore, this analysis was aimed at studying the mathematical modeling of the effects of $A$. philippense phytochemicals on adhesive to biofilm formation with their antibacterial properties against the food pathogen Shigella flexneri.

\section{MATERIALS AND METHODS}

A previously published data [15] for Shigella flexneri was processed using the software Webplotdigitizer 2.5 [16].

\section{Fitting of the data}

Nonlinear regression was carried out using the CurveExpert Professional software (Version 1.6). Several popular growth models were utilized in this study (Table 1). The $\mu$ max of the estimation was performed by the steepest ascent rifle of the curve, whereas the $\mathrm{x}$-axis crossing of this line is an estimate of $\lambda$. For the purposes of modeling, the model that demonstrates the highest growth was adopted.

Table 1. Growth models used in modelling the growth curve of the bacterium.

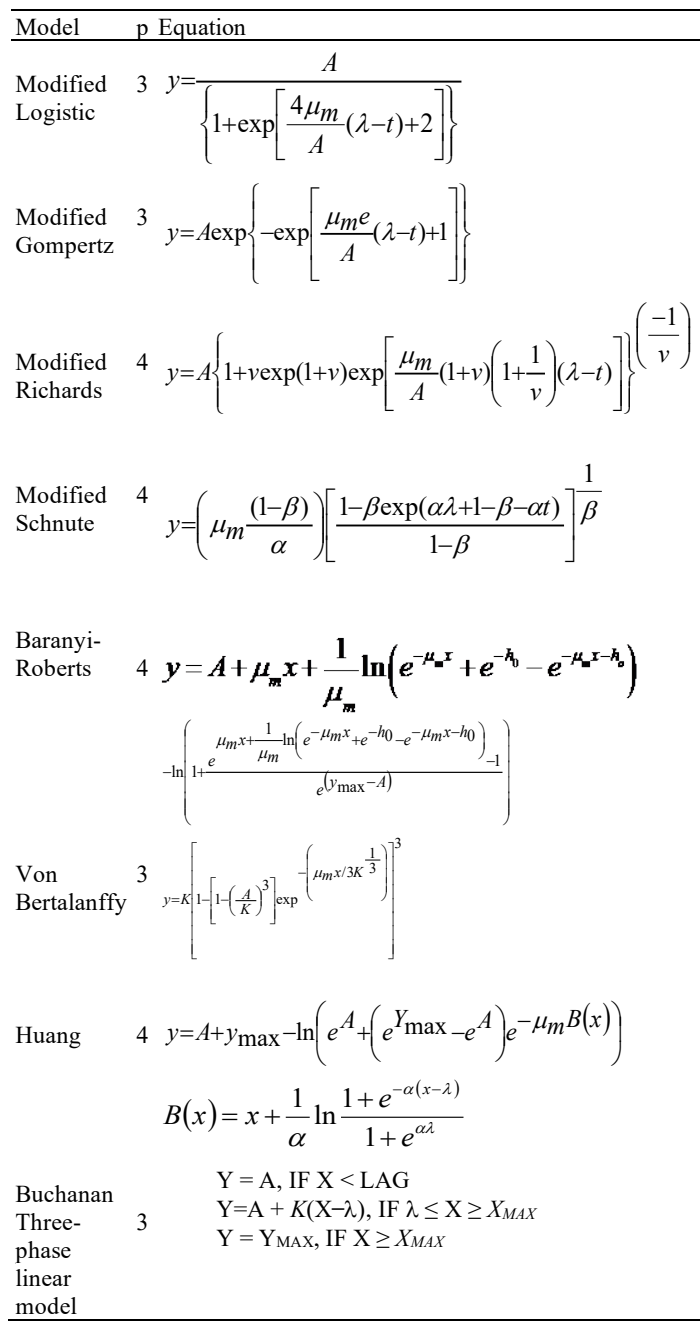

Note:

A= growth lower asymptote;

$\mathrm{A}=$ growth lower asymptote;
$y_{\max }=$ growth upper asymptote;

$y_{\max }=$ growth upper asymptote;
$\mu_{\max }=$ maximum specific growth rate;

$\mathrm{v}=$ affects near which asymptote maximum growth occurs.

$\mathrm{l}=$ lag time

$\mathrm{e}=$ exponent (2.718281828)

$\mathrm{t}=$ sampling time

$\mathrm{a}, \mathrm{b}, \mathrm{k}=$ curve fitting parameters

$h_{0}=$ a dimensionless parameter quantifying the initial physiological state of the reduction proces The lag time $\left(\mathrm{h}^{-1}\right)$ or $\left(\mathrm{d}^{-1}\right)$ can be calculated as $h_{0}=m_{\max }$ 


\section{Statistical analysis}

An error function assessment, which included statistical parameters such as accuracy factor (AF), bias factor (BF), adjusted determination coefficient (R2), root-mean-square error (RMSE), and one relating to information theory, the AICc, was used in the choice of the appropriate models (corrected Akaike Information Criterion) [36].

\section{RESULTS AND DISCUSSION}

Prior to modelling, the growth curves were replotted and converted to $\log$ units (see Fig. 1) to ensure that they were comparable. During the modelling phase, the highest signal was utilised to determine which model was the best. It was clear that all of the models had a good match to the growth curve (Figs 2 to 9). The modified Gompertz model was used to find the optimal model, which had the lowest values for RMSE and AICc, as well as the highest value for adjusted R2, among other characteristics. The $\mathrm{AF}$ and $\mathrm{BF}$ values for the model were demonstrated to be excellent, with their values being the closest to unity. The modified logistic model had the lowest overall performance (Table 2). The lack of a significant lag phase for growth is most certainly the explanation for the superiority of the von Bertalanffy model over other growth models. These are the coefficients for the modified Gompertz model, which can be found in Table 3.

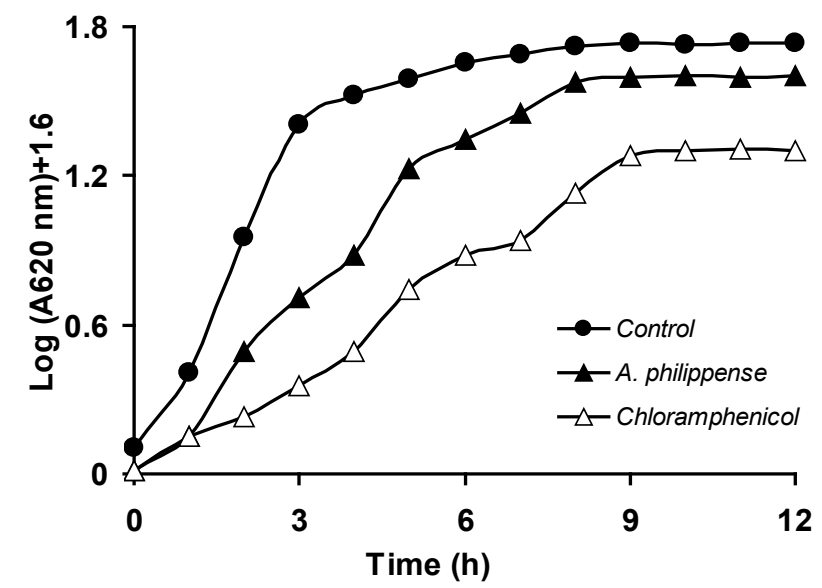

Fig. 1. Growth of $S$. flexneri biofilm (control) in the presence of $A$. philippense and a positive control (chloramphenicol).

Table 2. Statistical analysis of the various fitted models.

\begin{tabular}{llllllll}
\hline Model & $p$ & RMSE & $R^{2}$ & $a d R^{2}$ & AF & BF & AICc \\
\hline Huang & 4 & 0.068 & 0.989 & 0.983 & 1.036 & 1.020 & -48.22 \\
Baranyi-Roberts & 4 & 0.043 & 0.995 & 0.993 & 1.025 & 1.006 & -59.81 \\
modified Gompertz & 3 & 0.034 & 0.997 & 0.996 & 1.055 & 0.972 & -72.13 \\
Buchanan-3-phase & 3 & 0.081 & 0.982 & 0.975 & 1.055 & 1.011 & -49.76 \\
modified Richards & 4 & 0.036 & 0.997 & 0.995 & 1.040 & 0.983 & -64.83 \\
modified Schnute & 3 & 0.036 & 0.997 & 0.995 & 1.040 & 0.983 & -64.83 \\
modified Logistics & 3 & 0.046 & 0.994 & 0.992 & 1.048 & 1.026 & -64.60 \\
von Bertalanffy & 4 & 0.041 & 0.996 & 0.994 & 1.148 & 0.892 & -67.58 \\
& & & & & & & \\
Note: no of parameters & & & & & & \\
$p \quad$ ndR ${ }^{2} \quad$ Adjusted Coefficient of determination & & & & \\
BF Bias factor & & & & & & \\
AF Accuracy factor & & & & & & & \\
& & & & & & &
\end{tabular}

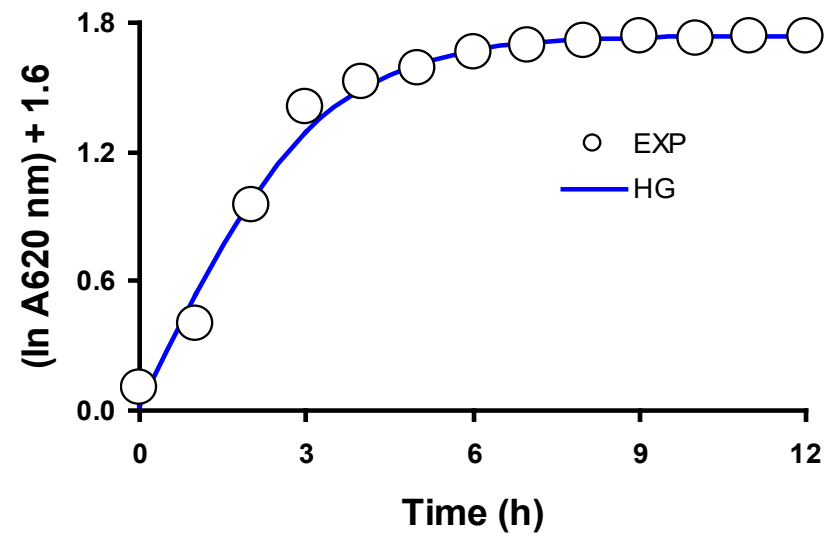

Fig. 2. Growth of S. flexneri biofilm (control) fitted to the Huang model.

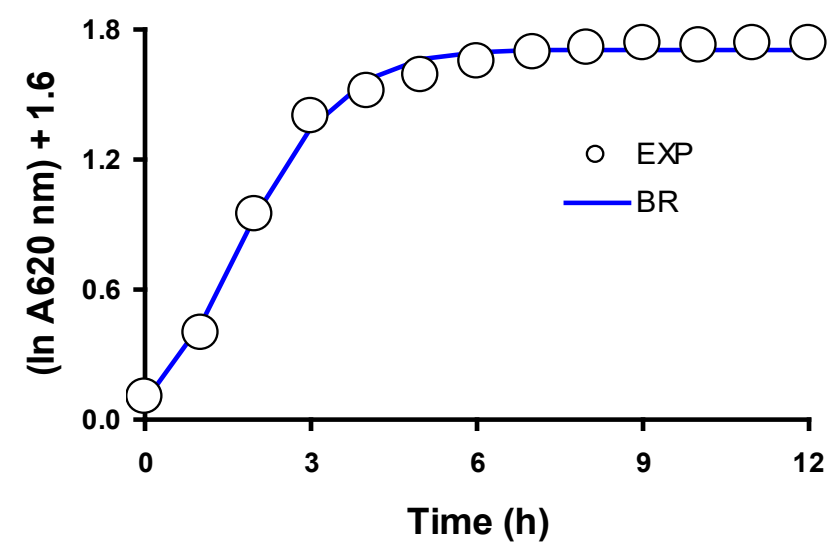

Fig. 3. Growth of S. flexneri biofilm (control) fitted to the BaranyiRoberts model.

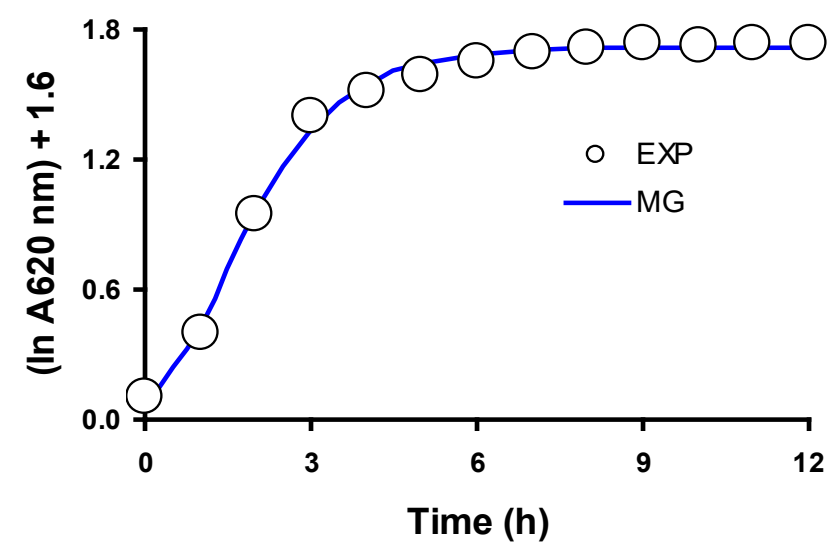

Fig. 4. Growth of S. flexneri biofilm (control) fitted to the modified Gompertz model. 


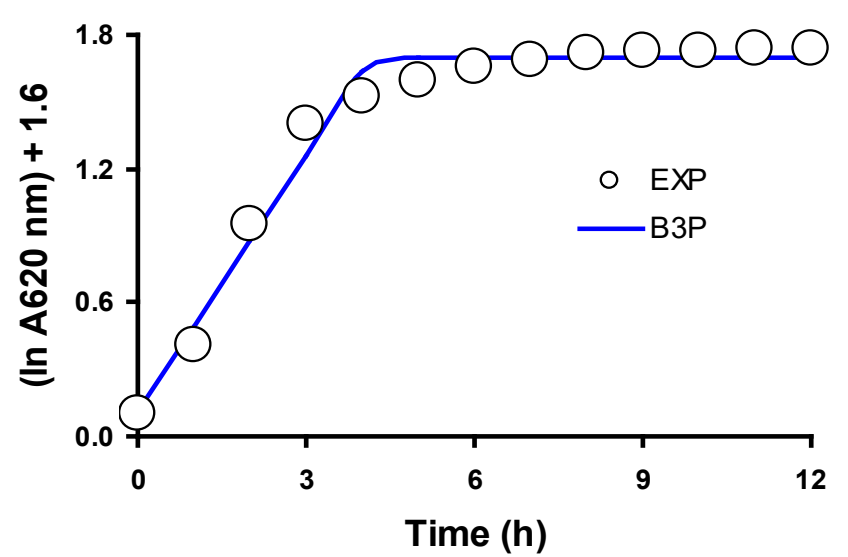

Fig. 5. Growth of S. flexneri biofilm (control) fitted to the Buchanan-3phase model.

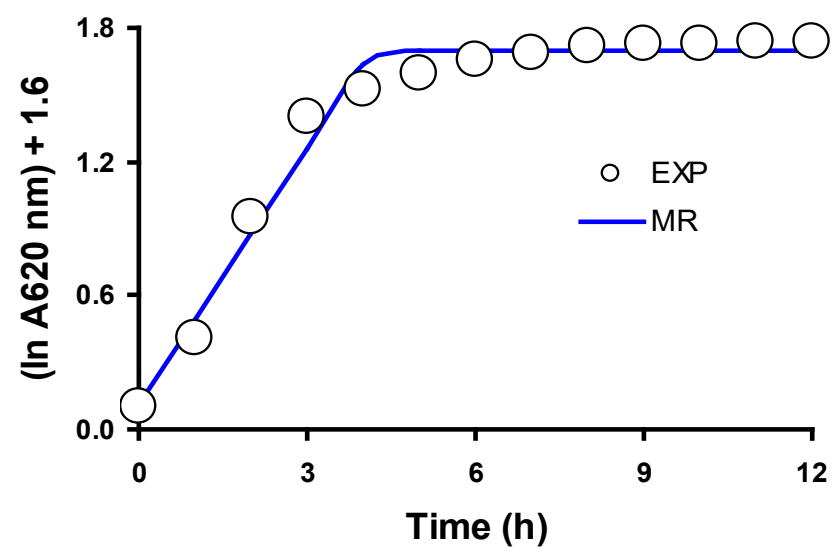

Fig. 6. Growth of S. flexneri biofilm (control) fitted to the modified Richards model.

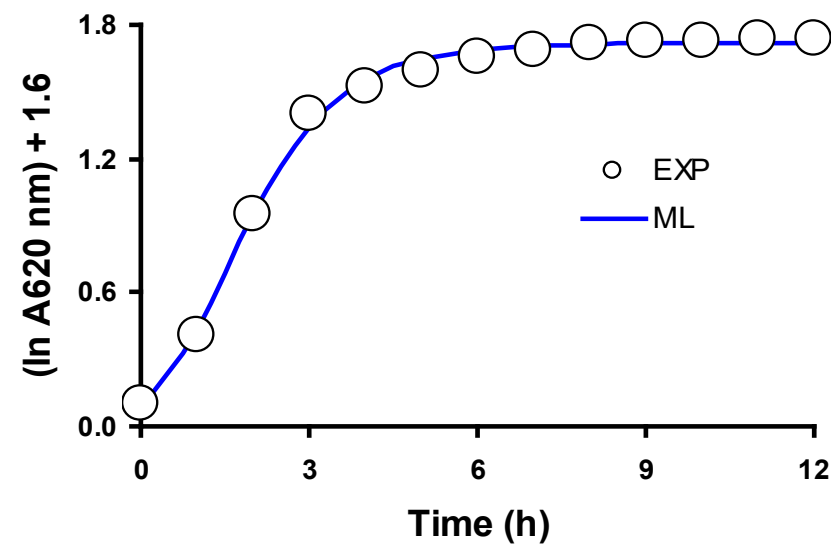

Fig. 7. Growth of S. flexneri biofilm (control) fitted to the modified logistics model.

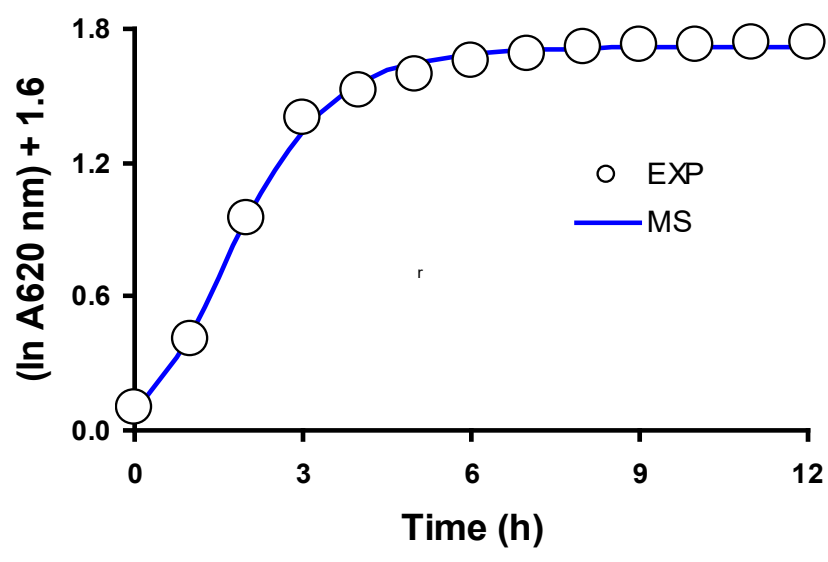

Fig. 8. Growth of S. flexneri biofilm (control) fitted to the modified Schnute model.

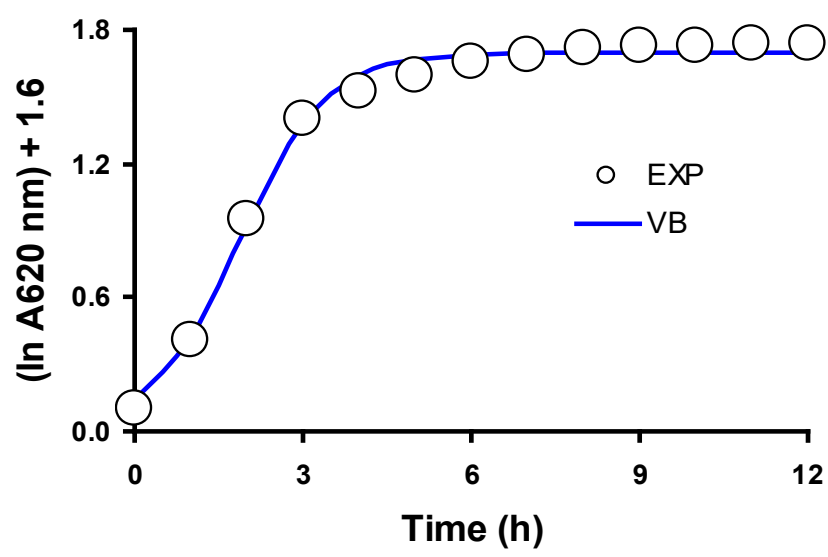

Fig. 9. Growth of S. flexneri biofilm (control) fitted to the von Bertalanffy model.

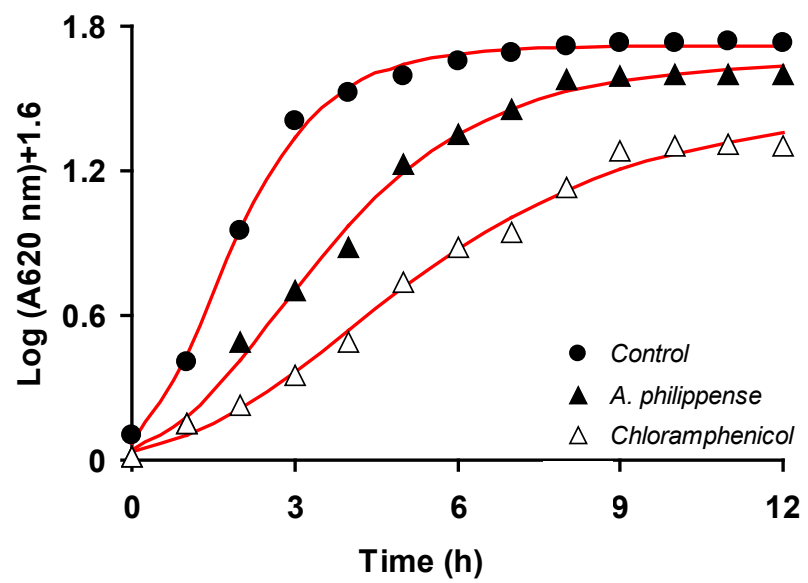

Figure 3. Growth of S. flexneri biofilm (control) in the presence of $A$. philippense and a positive control (chloramphenicol) fitted to the modified Gompertz model. 
Table 3. Table 3. Coefficients of bacterium biofilm (control) in the presence of A. philippense and a positive control (chloramphenicol) fitted to the modified Gompertz model.

\begin{tabular}{lcccccc}
\hline & \multicolumn{2}{c}{$\begin{array}{c}\text { Control } \\
\text { Value (95\% C.I.) }\end{array}$} & \multicolumn{2}{c}{$\begin{array}{c}\text { S. flexneri } \\
\text { Value }(95 \% \text { C.I.) }\end{array}$} & \multicolumn{2}{c}{$\begin{array}{c}\text { Chloramphenicol } \\
\text { Value }(95 \% \text { C.I.) }\end{array}$} \\
\hline$Y_{\max }$ & 1.719 & 1.689 to 1.748 & 1.650 & 1.585 to 1.715 & 1.455 & 1.329 to 1.580 \\
$\mu_{\max }\left(\mathrm{h}^{-1}\right)$ & 0.540 & 0.481 to 0.599 & 0.292 & 0.254 to 0.331 & 0.177 & 0.152 to 0.203 \\
$\operatorname{lag}(\mathrm{h})$ & 0.204 & 0.019 to 0.388 & 0.588 & 0.220 to 0.956 & 0.954 & 0.431 to 1.476
\end{tabular}

Note: $95 \%$ C.I. denotes $95 \%$ confidence interval.

The maximum specific growth rate $\left(\mathrm{m}_{\max }\left(\mathrm{h}^{-1}\right)\right.$ for $S$. flexneri treatment with $A$. philippense extract was significantly much lower $(\mathrm{p}<0.05)$ with a value of $0.292(95 \%$ confidence interval of 0.254 to 0.331 ) compared to control with a value of $0.540(95 \%$ confidence interval of 0.481 to 0.599 ) indicating potential biofilm inhibition. The study carried out here attempt to optimize bacterial growth using mathematical models. Other growth models that are available including Baranyi-Roberts $[17,18]$ and Logistic, modified Gompertz [19-25], Richards, Schnute $[26,27]$, Von Bertalanffy [28,29], Buchanan three-phase [22,3034] and more recently the Huang model [35]. The modified Gompertz model is the most popular model as it is the simplest (having three parameters). Previously, the mathematical modelling of the effect of Adiantum philippensis Extract and Adhesion to several bacteria have been studied with the best models for $P$. aeruginosa, $S$. aureus and $E$. coli was found to be von Bertalanffy [36], modified Gompertz [3] and von Bertalanffy [37] respectively. The advantage of mathematical modelling is statistical inferences can be made from differences of the parameters, especially specific growth rate. If the $95 \%$ confidence interval do not overlap, then there is a significant chance that the difference is significant at the 0.05 alpha value.The asymmetrical sigmoidal form of the modified Gompertz model, as opposed to the logistic model, provides greater flexibility than the logistic model. At the moment of inflection, sigmoidal models such as logistics and Gompertz differ primarily in the distance between the lower and higher asymptotes. There is a gap of $1 / 2$ and $1 / \mathrm{e}$ between the lower and higher asymptotes of the logistics and Gompertz models, correspondingly, between both the lower and upper asymptotes of the logistics model [38]. In principle, many growth models feature a changeable inflection point between the lower and higher asymptotes, as well as a flexible function of the slope between them. Each of these functions is either a distinct function or a reduced version of a parent model. Examples of such models are the modified logistics, modified Gompertz, and von Bertalanffy growth models, all of which are derived from the parental Richard's model [27,38,39].

The model has its limitations with the most important being that in the static version, $y_{(t=0)}$ is not equal to $y_{0}$. Second, the sigmoidal curve has an intrinsic trait of having an inflection point, which causes the model to have a systematic problem expressing the exponential phase of the distribution (Baranyi et al., 1993). In the end, the model seems to overemphasize the significance of its parameters [40-42]. The modified Gompertz model, in spite of this, has been widely applied to the modelling of the evolution of bacteria and secondary bacterial products, such as biogas, methane, lactate, biodiesel, and bacterioricin, just to mention a few [43-47] including callus growth [48-50]. Its usage for modelling the effect of biological extracts to biofilmforming bacteria has been reported for $S$. aureus [3], inhibitory effect of royal jelly on Listeria monocytogenes biofilm [51], inhibitory curves of Mexican Oregano (Lippia berlandieri Schauer) Essential Oil on biofilms of Pseudomonas aeruginosa and Salmonella Thyphimurium [13] and the inhibitory curves of two mangrove species, Bruguiera cylindrica and Laguncularia racemose on selected bacterium, yeast, and filamentous fungi biofilms [12]. For more secondary modeling, parameters derived from the fitting exercise may later be used. These mechanistic models aim to gain a better understanding of the processes of chemistry, physics and biology. Mechanistic models, such as the modified Gompertz, are more effective compared to purely empirical model, as mechanistic models tells us about the underlying mechanism or mechanisms that drive the effects of Adiantum philippense Extracts on Biofilms Formation and Adhesion to Shigella flexneri [52].

\section{CONCLUSION}

In concluding, the modified Gompertz model was found to be the most accurate model for modelling the inhibitory effects of Adiantum philippensis extracts on S. flexneri biofilm formation based on statistical tests such as root-mean-square error (RMSE), adjusted coefficient of determination $\left(R^{2}\right)$, accuracy factor (AF), bias factor (BF) and corrected AICC. Our data suggest that $A$. philippense extract was active against $S$. flexneri, and there is a potential usage of the plant for inhibiting bacterial biofilm.

\section{REFERENCE}

1. Nascimento TL, Oki Y, Lima DMM, Almeida-Cortez JS, Fernandes GW, Souza-Motta CM. Biodiversity of endophytic fungi in different leaf ages of Calotropis procera and their antimicrobial activity. Fungal Ecol [Internet]. 2015 Apr [cited 2020 Dec 15];14:79-86. Available from: https://linkinghub.elsevier.com/retrieve/pii/S1754504814001366

2. Singh SK, Rajkumar SD. Intraspecific Assessment of Adiantum philippense Linn. from Uttar Pradesh, India. Cytologia (Tokyo). 2018;83(2):165-7.

3. Uba G, Ginsau MA, Aujara KM. Biofilm Formation, Adhesion with Staphylococcus aureus Against Food Borne Pathogen: A Mathematical Modeling on the Effects of Adiantum phillippense. J Biochem Microbiol Biotechnol. 2020 Dec 28;8(2):25-9.

4. Donlan RM. Biofilm Formation: A Clinically Relevant Microbiological Process. Clin Infect Dis [Internet]. 2001 Oct 15 [cited 2020 Dec 15];33(8):1387-92. Available from: https://academic.oup.com/cid/article-lookup/doi/10.1086/322972

5. Adnan M, Patel M, Deshpande S, Alreshidi M, Siddiqui AJ, Reddy $\mathrm{MN}$, et al. Effect of Adiantum philippense Extract on Biofilm Formation, Adhesion With Its Antibacterial Activities Against Foodborne Pathogens, and Characterization of Bioactive Metabolites: An in vitro-in silico Approach. Front Microbiol [Internet]. 2020 May 13 [cited 2020 Dec 15];11:823. Available from:

https://www.frontiersin.org/article/10.3389/fmicb.2020.00823/full

6. Bihary D, Tóth M, Kerényi Á, Venturi V, Pongor S. Modeling bacterial quorum sensing in open and closed environments: Potential discrepancies between agar plate and culture flask experiments. J Mol Model. 2014;20(7)

7. Zhou S, Zhang A, Yin H, Chu W. Bacillus sp. QSI-1 modulate quorum sensing signals reduce Aeromonas hydrophila level and alter gut microbial community structure in fish. Front Cell Infect Microbiol. 2016;6(DEC).

8. Patel B, Kumari S, Banerjee R, Samanta M, Das S. Disruption of the quorum sensing regulated pathogenic traits of the biofilmforming fish pathogen Aeromonas hydrophila by tannic acid, a potent quorum quencher. Biofouling. 2017;33(7):580-90.

9. Brackman G, Coenye T. Quorum Sensing Inhibitors as AntiBiofilm Agents. Curr Pharm Des. 2015 Jan 1;21(1):5-11.

10. Husain FM, Ahmad I, Al-thubiani AS, Abulreesh HH, AlHazza IM, Aqil F. Leaf Extracts of Mangifera indica L. Inhibit Quorum Sensing - Regulated Production of Virulence Factors and Biofilm in Test Bacteria. Front Microbiol. 2017;8:727.

11. Rahman MRT, Lou Z, Yu F, Wang P, Wang H. Anti-quorum sensing and anti-biofilm activity of Amomum tsaoko (Amommum tsao-ko Crevost et Lemarie) on foodborne pathogens. Saudi J Biol Sci. 2017 Feb 1;24(2):324-30. 
12. Glasenapp Y, Cattò C, Villa F, Saracchi M, Cappitelli F, Papenbrock J. Promoting Beneficial and Inhibiting Undesirable Biofilm Formation with Mangrove Extracts. Int J Mol Sci. 2019 Jan;20(14):3549.

13. Reyes-Jurado F, Munguía-Pérez R, Cid-Pérez TS, HernándezCarranza P, Ochoa-Velasco CE, Avila-Sosa R. Inhibitory Effect of Mexican Oregano (Lippia berlandieri Schauer) Essential Oil on Pseudomonas aeruginosa and Salmonella Thyphimurium Biofilm Formation. Front Sustain Food Syst. 2020;4:36.

14. Singh BN, Singh HB, Singh A, Singh BR, Mishra A, Nautiyal CSY 2012. Lagerstroemia speciosa fruit extract modulates quorum sensing-controlled virulence factor production and biofilm formation in Pseudomonas aeruginosa. Microbiology. 2012;158(2):529-38.

15. Adnan M, Patel M, Deshpande S, Alreshidi M, Siddiqui AJ, Reddy $\mathrm{MN}$, et al. Effect of Adiantum philippense extract on biofilm formation, adhesion with its antibacterial activities against foodborne pathogens, and characterization of bioactive metabolites: an in vitro-in silico approach. Front Microbiol [Internet]. 2020 [cited 2020 Dec 17];11. Available from: https://www.frontiersin.org/articles/10.3389/fmicb.2020.00823/ful 1

16. Rohatgi A. WebPlotDigitizer-Extract Data from Plots, Images, and Maps [Internet]. 2018 [cited 2019 Jan 1]. Available from: http://arohatgi. info/WebPlotDigitizer

17. Baranyi J, Roberts TA. A dynamic approach to predicting bacterial growth in food. Int J Food Microbiol. 1994;23(3-4):277-94.

18. Halmi MIE, Shukor MS, Johari WLW, Shukor MY. Evaluation of several mathematical models for fitting the growth of the algae Dunaliella tertiolecta. Asian J Plant Biol. 2014;2(1):1-6.

19. Wang J, Wan W. Kinetic models for fermentative hydrogen production: A review. Int J Hydrog Energy. 2009;34(8):3313-23.

20. Wu D, Yang Z, Tian G. Inhibitory effects of $\mathrm{Cu}$ (II) on fermentative methane production using bamboo wastewater as substrate. $\mathrm{J}$ Hazard Mater. 2011;195:170-4.

21. Nikhil GN, Mohan SV, Swamy YV. Systematic approach to assess biohydrogen potential of anaerobic sludge and soil rhizobia as biocatalysts: Influence of crucial factors affecting acidogenic fermentation. Bioresour Technol. 2014;165(C):323-31.

22. Tornuk F, Ozturk I, Sagdic O, Yilmaz A, Erkmen O. Application of predictive inactivation models to evaluate survival of Staphylococcus aureus in fresh-cut apples treated with different plant hydrosols. Int J Food Prop. 2014;17(3):587-98.

23. Germec M, Turhan I. Ethanol production from acid-pretreated and detoxified tea processing waste and its modeling. Fuel. 2018 Nov $1 ; 231: 101-9$.

24. Zhu H, Yang J, Xiaowei C. Application of Modified Gompertz Model to Study on Biogas production from middle temperature codigestion of pig manure and dead pigs. In 2019. Available from: https://www.scopus.com/inward/record.uri?eid=2-s2.0$85073809936 \&$ doi $=10.1051 \% 2$ fe 3 sconf $\% 2$ f201911803022\&partn erID=40\&md5=0fa78ace03714e813d88cd19a9c00567

25. Uba G, Yakasai HM, Abubakar A, Shukor MYA. Predictive Mathematical Modelling of the Total Number of COVID-19 Cases for Brazil. J Environ Microbiol Toxicol. 2020 Jul 31;8(1):16-20.

26. Gibson AM, Bratchell N, Roberts TA. Predicting microbial growth: growth responses of salmonellae in a laboratory medium as affected by $\mathrm{pH}$, sodium chloride and storage temperature. Int $\mathrm{J}$ Food Microbiol. 1988;6(2):155-78.

27. Zwietering MH, Jongenburger I, Rombouts FM, Van't Riet K. Modeling of the bacterial growth curve. Appl Environ Microbiol. 1990;56(6):1875-81.

28. Cloern JE, Nichols FH. A von Bertalanffy growth model with a seasonally varying coefficient. J Fish Res Board Can. 1978;35(11):1479-82.

29. Darmani Kuhi H, Kebreab E, Lopez S, France J. A derivation and evaluation of the von Bertalanffy equation for describing growth in broilers over time. J Anim Feed Sci. 2002;11(1):109-25.

30. McClure PJ, Beaumont AL, Sutherland JP, Roberts TA. Predictive modelling of growth of Listeria monocytogenes. The effects on growth of $\mathrm{NaCl}, \mathrm{pH}$, storage temperature and $\mathrm{NaNO} 2$. Int $\mathrm{J}$ Food Microbiol. 1997;34(3):221-32.

31. Xiong R, Xie G, Edmondson AE, Sheard MA. A mathematical model for bacterial inactivation. Int $\mathrm{J}$ Food Microbiol. 1999;46(1):45-55.
32. Koseki S, Isobe S. Growth of Listeria monocytogenes on iceberg lettuce and solid media. Int J Food Microbiol. 2005;101(1-2):21725.

33. Okubara PA, Bonsall RF. Accumulation of Pseudomonas-derived 2,4-diacetylphloroglucinol on wheat seedling roots is influenced by host cultivar. Biol Control. 2008;46(3):322-31.

34. Kwak Y-S, Bonsall RF, Okubara PA, Paulitz TC, Thomashow LS, Weller DM. Factors impacting the activity of 2,4 diacetylphloroglucinol-producing Pseudomonas fluorescens against take-all of wheat. Soil Biol Biochem. 2012;54:48-56.

35. Huang L. Growth kinetics of Escherichia coli O157:H7 in mechanically-tenderized beef. Int J Food Microbiol 2010;140(1):40-8.

36. Uba G, Yakubu A, Abdulsalam ZJ, Shukor MY. Predictive Mathematical Modeling Biofilm Potential of Phytochemicals from Adantum philippensis Extract and Adhesion with P. aeruginosa Activities. J Environ Bioremediation Toxicol. 2020 Dec 31;3(2):15.

37. Uba G, Ginsau MA, Zandam ND, Shukor MY. Mathematical Modeling of the Effect of Adiantum philippense Extracts on Biofilms Formation, Adhesion with E. coli Activities Against Foodborne Pathogens. J Environ Microbiol Toxicol. 2020 Dec $31 ; 8(2): 6-11$.

38. López S, Prieto M, Dijkstra J, Dhanoa MS, France J. Statistical evaluation of mathematical models for microbial growth. Int J Food Microbiol. 2004;96(3):289-300.

39. Gibson AM, Bratchell N, Roberts TA. The effect of sodium chloride and temperature on the rate and extent of growth of Clostridium botulinum type A in pasteurized pork slurry. J Appl Bacteriol. 1987;62(6):479-90.

40. McKellar RC, Knight K. A combined discrete-continuous model describing the lag phase of Listeria monocytogenes. Int J Food Microbiol. 2000;54(3):171-80.

41. Membré J-M, Ross T, McMeekin T. Behaviour of Listeria monocytogenes under combined chilling processes. Lett Appl Microbiol. 1999;28(3):216-20.

42. Whiting RC. Modeling bacterial survival in unfavorable environments. J Ind Microbiol. 1993;12(3-5):240-6.

43. Espeche MC, Tomás MSJ, Wiese B, Bru E, Nader-Macías MEF. Physicochemical factors differentially affect the biomass and bacteriocin production by bovine Enterococcus mundtii CRL1656. J Dairy Sci. 2014;97(2):789-97.

44. Kargi F, Eren NS, Ozmihci S. Effect of initial bacteria concentration on hydrogen gas production from cheese whey powder solution by thermophilic dark fermentation. Biotechnol Prog. 2012;28(4):931-6.

45. Karthic P, Joseph S, Arun N, Varghese LA, Santhiagu A. Biohydrogen production using anaerobic mixed bacteria: Process parameters optimization studies. J Renew Sustain Energy. 2013;5(6).

46. Mathias SP, Rosenthal A, Gaspar A, Aragão GMF, Slongo-Marcusi A. Prediction of acid lactic-bacteria growth in Turkey ham processed by high hydrostatic pressure. Braz J Microbiol. 2013;44(1):23-8

47. Mohammadi M, Mohamed AR, Najafpour GD, Younesi H, Uzir MH. Kinetic studies on fermentative production of biofuel from synthesis gas using clostridium ljungdahlii. Sci World J. 2014;2014.

48. Omar R, Abdullah MA, Hasan MA, Rosfarizan M, Marziah M. Kinetics and modelling of cell growth and substrate uptake in Centella asiatica cell culture. Biotechnol Bioprocess Eng. 2006;11(3):223-9.

49. Shukor MS, Masdor NA, Halmi MIE, Ahmad SA, Shukor MY. Test of randomness of residuals for modified Gompertz model used for modelling the growth of callus cultures from Glycine wightii (Wight \& Arn.) Verdc. Asian J Plant Biol. 2015;3(1):11-3.

50. Shukor MS, Masdor NA., Halmi MIE, Ahmad SA, Shukor MY. Modelling the growth of callus cultures from Glycine wightii (Wight \& Arn.) Verdc. Asian J Plant Biol. 2015;3(1):20-5.

51. Altuntas S, Cinar A, Altuntas V. Modelling of Listeria monocytogenes growth and survival in presence of royal jelly, a promising anti-biofilm agent. J Food Nutr Res. 2020 Jan;59(1):715 .

52. Bolker BM. Ecological Models and Data in R. Princeton, N.J: Princeton University Press; 2008. 408 p. 